DOI: $10.15593 / 2499-9873 / 2020.3 .07$

УДК 338.2

Original Russian text: Логиновский О.В., Максимов А.А. Стратегическое управление регионами: от сложившихся подходов к учету современных реалий // Проблемы управления. - 2017. - № 6. - С. 19-31.

\author{
O.V. Loginovskiy ${ }^{1}$, A.A. Maksimov ${ }^{2}$, A.L. Shestakov ${ }^{1}$ \\ ${ }^{1}$ South Ural State University, Chelyabinsk, Russian Federation \\ ${ }^{2}$ The State Duma of the Federal Assembly \\ of the Russian Federation, Moscow, Russian Federation
}

\title{
STRATEGIC MANAGEMENT OF THE REGIONS IN THE CONTEXT OF DOMESTIC AND FOREIGN EXPERIENCE
}

The results of analyzing the approaches, concepts, programs, as well as the practices of strategic management of regional development, existing in Russia and abroad, are presented. Based on the revealed trends and taking into consideration the factors of global instability in the world, a complex of scientific provisions is worded with regard to forming of a relevant management strategy for social and economic development of regions in modern-day Russia. The suggested approach includes 10 provisions.

1. The strategy of the region social and economic development should be considered as an integral structure of subsystems taking into account the whole range of its natural, economic and social components, which constitute a unified territorial complex with multiple intricate internal and external relations.

2. It is necessary to analyze the social and economic status of the region in the totality of the fields of its production-and-economic activities; and compare the relevant set of indicators, provided by the state and regional statistics, to the available data obtained as a result of monitoring the functioning of the industrial enterprises.

3. The strategic priorities in the social and economic development of industrial enterprises in the Russian Federation entity should be formed through a system of supporting the making of managerial decisions on the region's development, which would include the earlier mentioned methods, models and program complexes of the information-and-analytical system.

4. Russian Federation entities should elaborate the strategies of their social and economic development in compliance with the Forecast of the Science and Technology Development in the Russian Federation for the Period till 2030.

5. Since Russian Federation entities, in their essence, are integral formations with a unified wide range of natural, economic and social components, and are interested in proportionate and wellbalanced development of those, it means that in order to ensure the strategic industrial and economic priorities of these regions, it is necessary to perform a complex analysis of the supporting infrastructure subsystems (engineering and technical facilities and communications, resources of all kinds, etc.) for the industrial enterprises being developed.

6. The concepts and programs of the social and economic development of regions should not only be properly elaborated and informationally tied to relevant federal programs.

7. No matter the scale of the regional development plans and the ambitions within those, as formed by the regional departments of state authorities, all of that can only be fulfilled by the population of those entities.

8. The strategy of social and economic development of any region, as a rule, comprises the programs for development of the secondary and higher professional education, the forming of which should be based on the forecasts of the demographic increase of population, development of industrial enterprises and organizations located on the region's territories, etc.

9. It is impossible to fulfill the strategies of the development of Russian Federation entities without such an important component as public healthcare. 
10. Various social programs and social protection of the population in general should be one of the crucial aspects when forming the strategies of development of Russian Federation entities

Keywords: organizational behavior control, strategic management, social and economic system, sustainable development, region management, integral structure, analisys, monitoring, information-and-analytical system, industrial enterprises, professional education, public healthcare, social programs, social protection.

\section{Introduction}

This article is based on materials published in the original Russian text [1], and purpose of it article consists popularizing abroad the authors' and other scientist's results in the field of organizational behavior control in social and economic systems.

Strategic management in regions should not be considered separately, without the interconnection with the goals, tasks and criteria of reaching these at the level of a country in general, federal governmental target programs and big-scale projects, which often have significant influence on development of economic zones and certain territories of the Russian Federation entities. Strategic management in regions should be setting the objectives for development of major industrial enterprises and other economic entities in cities and territories, as well as determining the strategic priorities for local authorities.

The issues of federal state and regional strategic management are covered in numerous works of scientific and engineering literature, including in [2-40]. On the other hand, there is a big number of scientific works written on the topic related to state administration - strategic management at industrial enterprises and organizations, in particular [2-21, 41-56].

It is important to be realizing that in their historical development, the ideas, approaches, concepts, methods and technologies of state, regional, municipal and corporate management underwent the evolution based on the achievements and results of each other. New approaches and concepts were being created with the background of severe competition between countries and economic zones, transnational corporations, regions and territorial entities within certain states, and leaders of sector-related businesses, etc. Naturally, such competition was accompanied by political and economic victories of some and losses of the others, what changed not only the essence of the economic approaches, but also the social and political platforms, and even the political regimes.

Before we speak on which concept of regional strategic management is needed in Russia in the modern conditions of growing instability in the world, we should try to make sense of what we should learn from the Russian and foreign historical experience in social and economic development. 


\section{Analysis of the conceptual framework and practices of strategic management in Russia and abroad}

The traditions of state, regional and corporate management in Russia have been forming under the influence of a combination of natural, historical and political, and social factors, which had a significant effect on the peculiarities and dynamics of social and economic transformations [22, 23, 47, 57].

It is well known that after the socialist revolution, private industrial enterprises became the property of the government, and that is why it was namely the governmental and party authorities who began to determine the main strategy of development of those based on centralized planning of the development of the whole national economy. The leadership of enterprises mostly performed operational production management aimed at uncompromising fulfillment of the directive plans approved by the superior authorities. In those years, the interrelation between the state and regional strategic policies in all the fields of national economy was based on completely centralized financial and economic system, and on distribution of resources through the Soviet Union's government budget. Within this system, a region was seen as a territorial entity with a system-forming economical foundation based on sector-related production structures with centralized management. In the Soviet model of economics, among the many stages of its development (War Communism, New Economic Policy, etc.), the most significant achievements and economic results were seen only in the periods of administration based on command-and-control system with strict Five-Year-Plans. Therefore, both the very structure of the territorial entities in modern Russia and the sectors' makeup of the major industrial enterprises originate from those created in the Soviet Union and do not differ from them that much. This is related to the fact that the post-Perestroika Russian economics is based on redistributing of the governmental resources, which were centralized in the past, in favor of the entities, which earlier were the structural elements of the command-and-distribution economics and which still stick to its characteristic peculiarities, both in its internal structure and when interacting with the government authorities [47].

We should note that the forms and methods of the centralized FiveYear-Planning (with annual amendments) were used in the administration of the country and its regions all through the middle of the 1980s. The results of the based on the Five-Year-Plans strategic management of the state proved to 
be highly efficient and allowed the Soviet Union to become one of the major industrial powers in the world already back in the first half of the 20th century, become winners in World War II against the Nazi Germany, and secure quick recovery of the national economy, which was destroyed by the war, and after that achieve parity with the USA in military engineering, and even outcompete them in certain fields, for instance, in space exploration.

At the same time, starting from the second half of the 1970s, the social and economic development of the Soviet Union began to slow down and even deteriorate, though it still provided for social stability in the society. In this context, from the late 1980s, the Soviet Union leadership started making attempts at modernizing the administration of the country by introducing the elements of market transformations. This period of Russian history was characterized with dramatic decline in industrial production, in standards of living, and so on $[5,6]$.

Our country actually pulled out of planning its future and competing with the U.S.-led top capitalist countries, and having changed its status into a modest regional power in the system of world economy. While at the same time the practices of strategic management showed completely opposite trends in foreign countries.

The world's leading powers came to be realizing the importance of strategic planning and management as the outstanding success resulting from the first Five-Year-Plans started to show in the national economy of the USSR. For instance, the USA began adopting the Soviet Union's practices of governmental regulation of the economy processes already in 1933. The use of these practices became a key saving remedy for getting the American economics out of the Great Depression. It was namely then that the idea, that the "invisible hand of the market" could help efficiently manage the economics of the major capitalist states, was cast doubt on. It turned out that the government's intervention into the economics by introducing the elements of centralized planning and development of target programs in construction industry, agriculture and other sectors facilitates the public employment and boosts the dynamics of industrial growth. In particular, the USSR's experience of industrialization served as a methodological base for the elaboration of the Tennessee Valley Authority Act - an iconic result, which was achieved thanks to the American target program of regional development fulfilled with the support from the USA President F. Roosevelt. This program made possible the creation of a system of artificial water res- 
ervoirs, ensuring a complex amelioration of agricultural lands, improvement of the ecological situation in the region, increasing of the growth of agricultural goods production, development of seafaring and the system of transport communication; and cutting of the electricity tariffs initiated by the local administration, despite the objections from private companies, gave impetus to the economic growth, attracted many private entrepreneurs, increased the volume of products manufactured by industrial enterprises, as well as facilitated the evolving of a developed social infrastructure.

Thus, the wide range of the American target programs (the term program in the American understanding is known to imply multiple meanings and can essentially comprise any type of managerial activity), which are being developed and fulfilled, including in the science-intensive fields (various programs on space exploration, strategic defense initiative, etc.), in their core originate from the practices of strategic planning elaborated in Russia.

We should note that many foreign big-scale programs are based on the interests of major businesses and do not always get support from the population. Those are especially important for regional economics during the periods of production decline.

In Japan, the role of target programs is particularly visible in such science-intensive sectors as electronics, robotics, and information systems. Meanwhile, the companies and corporations are not forced upon certain indicators in the manufacture volume for this or that product, but are rather suggested with only basic objectives required for the development of the private entrepreneurship and the country in general. Thus, strategic economic planning, including through influencing the production dynamics by indicative plans, sets the required objectives for the private companies, while allowing the government to control the main trends of the country's economic development.

We could give many examples of different target programs in France, United Kingdom, Germany, and other countries. Such programs are mostly used to fulfill projects and develop productions with long payoff periods. Those, along with government businesses, serve as main mechanisms of a government's participation in the economic life of the Western European countries. In particular, government businesses ensure support for the traditional industrial sectors of these countries: coal mining, shipbuilding, metallurgy, and others.

France, in its strategic management, uses medium-term programs of economic and social development intended for 4 to 5 years, as well as short-term economic programs (called the economic budgets) for the period of 1 year. This 
could be considered an almost complete analogy of the USSR's Five-YearPlanning, were it not for significantly less strict requirements to the fulfillment of the plans. The mentioned French programs are not mandatory, they serve as recommendations and some kind of objectives for the private businesses.

The strategic management experience of the Federal Republic of Germany is related to the fact that, starting from the middle of the 1960s, the country's activities were mostly dominated by programs, the so-called "public tasks", which included monitoring of the economy situation in the regions, as well as taking measures on improving the regional economic structure. For these purposes, assets for the industry and infrastructure development are allocated from the federal and land budgets. Despite the government's declaring its nonintervention into the country's economic life, there is a certain mechanism of the so-called macroorientation of economics, which is used in the regional strategic management, and which essentially is nothing but a planned management of the economics.

In Norway, $90 \%$ of the country's territory is covered by regional target programs. In the United Kingdom, this indicator equals about $40 \%$.

It is indicative that practically in all European countries there exist special administration authorities dealing with the issues of regional development, as well as budget funds for supporting the territories' development. What is more, many European countries have created special governmental enterprises, which invest the financial resources of the state budget into development of the infrastructure of different territories. Thus, in the Sweden's province of Norrland, more than one third of the funds required for its development are allocated from centralized sources. Over one half of the assets intended for the development of industry in southern Italy are also provided by the state.

Nevertheless, the theoretical basics of strategic management, elaborated in the Western countries, are considered to be the major accomplishment in the modern world's managerial ideas. We should briefly mention those.

In USA, the theoretical developments on strategic management appeared in the 1940-1960s. Those are related to such names as L. White, F. Taylor, H. Gantt, F. and L. Gilbreth, T. Parsons, and many others. Among various theoretical developments created by the American scientists for modern managerial practices, of interest are the ideas on ensuring the integration and stability of the existing system of administrative-andgovernmental management based on the structural-functional method, as well as the concept of organized development [23]. 
In the United Kingdom, the theoretical research on administrativeand-governmental management began back in the end of the 19th century. In particular, already developed were the institutional approach to state administration, systems of "hard thinking" and then of "soft thinking", organizational cybernetics, and more [3].

Studies of the state administration problems in France came as a result of the development of the science of state (or constitutional) law. H. Fayol is rightfully considered to be a classical author on the theory of administrative-andgovernmental management in France. The management principles, which he worded, are multi-purpose and can be applied almost everywhere: in state administration, economics, and so on. Based on the institutional theory, the French school of administrative-and-governmental management formulated an institutional concept of a state, which replaced the interpretation of a state as a legal entity, that had been developed within the framework of the constitutional law. One of the major problems of the theory of administrative-andgovernmental management in France lies in the search for an optimal system of interrelations between the state apparatus and the citizens [3].

The theory of administrative-and-governmental management in Germany is mostly based on the philosophical-and-anthropological approach to state administration, what essentially formulates an idea of creating a "strong" state. A concept by W. Weber is widely known, in which a sociological approach to state administration is developed. However, with regard to the practices of modern state administration, the concept by L. Erhard seems to be most interesting, as it is related to increasing the social role of state administration and bringing the interests of all groups to the public welfare. Following this concept allowed Germany to recover after the war and achieve outstanding results thanks to reinstatement of its state budget through systematically reducing the governmental expenses, tax mitigation, prohibiting new hiring and salary increments, cutting business trips down to minimum, and so on [40].

From the early 1960s, the public-and-management disciplines start expanding in Europe. New managerial concepts evolved: school of public choice, neo-corporatism, school of sociology of organizations, and cognitive approach. In the 1980s, intensive research is conducted on network structures, specialized communities, and related phenomena. Later, the studying of those "communities" became only one of the possible aspects of analysis [23].

Today, in the developed countries a number of concepts compete, which substantiate the role of the state in managing its society: liberal con- 
cept (the public life is regulated by the free market); neoliberal concept (the economic process is regulated by the state acting as a product customer through contractual relationships with big corporations); socialist concept (promoting the principles of planned centralized state administration); and concepts combining the elements of the neoliberal and the socialist ones (reflecting the modern objective trend of the world's community development, which in terms of politics is characterized with the increasing role of the conscientious attitude factor in the form of forecasting and planning, regulating and managing activity of the state).

Despite the criticism towards the neoliberal model of the economic policy, there was a time when the Russian government chose namely this neoliberal model to base its strategy of the country's capitalization upon. A course was set on destroying the state regulation of the economics. In stark contrast to the theory, and the Russian and foreign experience, the "state property was qualified as "belonging to no one", and the quality of using it supposedly could not be assessed as per criteria of economic efficiency".

It is worth mentioning that there exist several theoretical approaches to studying state administration, which allow to analyze it from different aspects and points of view. Among those, the approaches can be distinguished, which are based on: theory of groups (state administration is assessed as a result of group competition, a conflict between different groups from society and government, and searching for a consensus in certain issues); concept of political process (state administration is seen as a result of political activity, which has fixed steps and phases in the process of solving public problems); theory of institutionalism (state administration is considered to be a result of the activity of state institutions, which use certain administrative procedures to reach the set goals); theory of elites (state administration is deemed a result of preference and choice of the political and administrative elites); theory of rationalism (state administration is viewed as a result of the activity on reaching optimal public goals while being guided by the developed technologies of management); theory of incrementalism (gradual approach) (state administration is fulfilled as a sequential step-bystep activity of the state bureaucracy on slowly changing the existing state of affairs, i.e. small variations on changing the previous condition); theory of games (state administration implies a rational choice in the competition between two most influential parties in the society or in the government); theory of public choice (state administration is seen as a result of the activity 
of individuals based on the realization of their own interests on making the corresponding decisions, which should bring certain benefits to them); theory of open systems (state administration is formed as a result of the respond by the political system to the requests and demands of relevant structures and factors of the external environment).

The most important characteristics of state policy, which it should generally possess, come down to a necessity to comply with the following criteria: responding to different changes occurring in the society and in the country; having a complex character and considering any problem as interrelated with other problems; being efficient and bringing results; and having the trust of the population [15].

Western countries believe that strategic management of a state must ensure: clearly determining the prospects, goals and tasks on achieving those; supplying resources for state administration in all the fields of economic activity; providing for the preparation of making decisions on state administration, fulfillment of the administration process itself, and solving of the problems arising along the way.

In the Soviet period, the ideas of scientific management were being developed by A.A. Bogdanov, N.A. Vitke, A.K. Gastev, O.A. Yermansky, E.F. Rozmirovich and many other scientists and practitioners, who were working in different organizations and institutions of scientific organization of labor [19]. Their ideas, concepts and developments originated from the criticism of the capitalist system and its economic activities based on private business. In their works, they elaborated theories, patterns and laws characteristic of the socialist system, including the planned development of the national economy through Five-Year-Plans, and so on.

It is necessary to be fully realizing that all these developments were based on the K. Marx's criticism of the concept of a dual character of management in capitalism, when the capitalist management was being understood not only as a special function originating from the very nature of the public progress of labor and relating to it, but also as a function of exploitation of the public process of labor, which is explained by the inevitable antagonism between exploiters and workers. Since the main goal of capitalist production is gaining a profit, then management, on one hand, is meant to coordinate the actions of all the participants of production and rationalize its organization; and on the other hand, it is intended to serve as a means of increasing the exploitation of the hired labor; and these two aspects of man- 
agement in the context of capitalist cannot be separated one from the other. As opposed to capitalist goals in the economics management, the main task declared by socialism implies the ensuring of "complete welfare and free all-round development of all the society members", what in theory eliminates the dual character of management attributed to capitalism, and creates the conditions for widely attracting the work people to managing of enterprises, as they are becoming the owners of the production means represented by the state. The economics management based on socialist ownership fundamentally changes not only the class-specific essence of management, but also its forms and methods. It becomes possible to performed planned organization of public production on a nation-wide scale. In this context, centralization and direct management of the enterprises' production activities by the state authorities are taken as the core idea of the Soviet school of management. The theories of functions, structures and processes of management at enterprises and government authorities are being developed, the patterns are being studied, and the laws are being formulated with regard to managing the socialist national economy (laws of the unity of the management system, proportionality of production and management, optimal ratio of centralization and decentralization of the management functions, participation of the work people in management, correlation between the managing system and the one being managed) [47].

From the late 1980s, the fundamental basics of socialism in the Russian science on management and economics were severely criticized, what ultimately depreciated all the developments in the management theory of that era. At the same time, due to the inertness, explained by the big scale, and to the difficulty of reforming huge mass production systems, some features of the socialist model of management were still preserved at big production structures [47]. On the other hand, many of the small productions in Russia were already being created during the post-Perestroika period of the economics development and were initially based on different things. This made the production-andeconomy complex of this country not quite homogenous.

Over the years of reforming, many Russian scientists, analytics, political figures and statesmen suggested a number of concepts on strategic management, scenarios and programs of social and economic development of Russia and its regions [11, 12, 17, 25, 26, 30, 31, 33-38, 58]. Many of these concepts and programs are based on the well-known models of regional management, which had been formed by the major scientific schools of eco- 
nomics and management (models by L.I. Abalkin, A.G. Granberg, D.S. Lvov, A.G. Porshnev, and others). Let us give one of the classical definitions of strategic planning $[12,34]$. Strategic planning is a process of developing of a strategic plan through formulating the goals and criteria of management, analyzing the problems and environment, determining strategic ideas and competitive advantages, choosing the scenarios and basic strategies of development, and making forecasts on the social and economic development. Meanwhile, a region is considered with regard to the duality of aspects: the economic and social development, which are joined by the natural aspect [34]. Therefore, when elaborating the strategic plans for a region's development, it is necessary to: analyze the internal and external environment of the region; come up with alternative variants of development; calculate the need for resources of various kinds; draw up the estimates of income and expenses (budget), etc.

The common problems of development in practically any Russian region, long-term, include the economy restructuring, providing of resources for the national economy, improving the demographic situation and the population's quality of living, and ensuring healthier environment and ecological safety [33, 34, 37].

Scientific literature also offers other approaches to solving the tasks on social and economic development in regions [4, 25, 26, 30, 36, 38]. A region may also be considered as a totality of sig macro-subsystems: regional economy; agricultural and industrial complex; as well as production, financial-and-economical, and management spheres. Each sphere comprises a number of subsystems, distinguished by sector (industry, transport, trade, education, culture, etc.) or the object of management (economics, finances, investments, personnel, market institutions, etc.). The prerogative of functional management of a region also includes managing the sectors of economy at the regional and city-wide levels. The strategy of regional development is formed based on program-and-target management, what implies the setting of strategic and tactical goals, as well as the criteria of reaching them the qualitative indicators, which determine the extent and content of assessing the goal's achievement, as compared to other possible variants of the region's development. Often, three variants of regional development are formed: the pessimistic, realistic, and optimistic ones.

We should note that already in the work [59] the concept of long-term strategy and economic reforms in Russia was being presented as based on 
the then new principles and mechanisms of interaction of the components of social and economic efficiency. The crucial role in it was supposed to be given to the system-and-institutional transformations. Those mostly aimed at creating powerful stimulation for the entrepreneurial and labor activity of people. In the development of the relationships of ownership, the priority was being given to improving the efficiency of its various forms, what would have ensured the multi-structure character of the economics. It was assumed that with consideration to the world trends in transformations, and the geopolitical and national-and-historical peculiarities of Russia, this country will take up the consistent movement towards a Russian variant of an information-and-industrial society with multi-sector and socially oriented market economy, as its powerful resource and spiritual potential and the main goal of social-and-economic development. This was supposed to facilitate the creation of a state strategy for development of the economics and society of Russia, and forming of its political and economic relations with the surrounding world for the foreseeable future (35-40 years). The same work states the goals of strategic management in the field of social policy and safety, and economic development.

As it was quite rightly stated in [17], it is necessary to prevent further increase of the gap between Russian and developed countries, medium-term; and recover and strengthen the positions of Russia as one of the leading countries in the world's development, long-term. This task is still on the agenda today. In this context, the three models of political regime in Russia considered in detail are of interest: stagnation model; highly authoritarian model; and authoritarian-and-democratic model. Namely the latter model was actually the one that was being fulfilled these last years. The general principle of resolving the authority crisis and strengthening of the state, long-term, turned out to be based on the following formula: strong executive authorities in the state, where law and order are ensured. Nevertheless, the Russian society is still suffering from the inefficiency of the nonconsolidated, inert and corrupted executive authorities, which are not capable of elaborating a reasonable economic policy and coherently conducting it. The country's president and government must guarantee stability, transparency and clarity of the "rules of the game" to all the participants of the economic process. This will help recover the trust to the state and authorities, and this way, among other things, will stimulate the return of capital withdrawn from Russia, as well as of investments [17]. 
As the ideologists of the market reforms see it, the scenario implying the withdrawal of a state from practically all spheres of economic activity, opening of the country to the outer world, and delegating many of the social functions to the private sector, should lead to significant economic growth, a one that for a short-time period will be higher than that in any other scenario. However, it is well known, that no such thing ever happened.

Among a whole range of other scenarios of social and economic development of a country and its regions $[11,12,25,26,30,31,33-38,58]$, there is also a scenario of modernization, according to which the main part is given to freeing the private initiative and to strengthening the role of the state in ensuring favorable conditions of the economic activity, including financial and social stability.

The conditions of fulfilling the development strategy of a region are also significant. A conceptual scheme of fulfilling such a strategy may be performed based on the recommendations suggested in work [50], where three stages of the strategy fulfillment are distinguished:

1) concentrating the resources in the strategically important fields of activity;

2) creating a viable management system based on efficient interaction of authorities, enterprises and organizations of a region;

3) achieving the strategic objectives based on the set goals and criteria of management.

Thus, the fulfillment of the development strategy is managed within complex target programs, which serve as a crucial instrument in the fulfillment of the strategic plan of development for a country and its regions. As part of the strategic plan, a list of complex target programs on the region's main macro-subsystems is elaborated.

Work [7] describes a cycle of the strategic planning of a region's economic development, where seven stages may be distinguished: determining the goals of the region's development; analyzing the external environment of the region's development; revealing strong and weak aspects within the region; analyzing the use of the available and creating new local advantages; elaborating the strategy and concept of the region's development; elaborating the plan of certain actions and fulfilling of the strategy; controlling the efficiency, and correcting the forms and methods of achieving the goals of the region's development. Using of the methods of regional marketing, benchmarking and other ones for the purpose of improving the efficiency of the regional strategic management is also considered. 
Over the years of reforming, a number of regional concepts has been created for managing the development of industrial enterprises, small businesses, social sphere, etc. (in particular, a concept was suggested for managing the development of the Chelyabinsk Region's industry [20, 22]). There are examples of both quite efficient solutions for such tasks and negative experiences, which show that the problem of regional development needs some serious thinking over, scientific assessment, and a more complex economically substantiated approach, including in part of the analysis of the social and economical development of territories, industrial and agricultural objects and entities of the Russian Federation in general. Recently, it has become popular to form the positions of strategic development for regions, cities and territories based on various surveys among the residents. While paying respect to the opinions of separate citizens, one should not forget that only about one hundredth of their percentage can be considered as management specialists who can properly assess and understand the goals and tasks of regional development at a professional level. That is why such surveys, as a rule, are only of populist character, and their results must not become the basis for forming the priorities of a region's development.

\section{Forming of a relevant management strategy for social and economic development of regions in modern Russia}

The analysis of the theory and practice of strategic state and regional management in Russia and abroad demonstrates that far from all the proposed ideas and concepts turned out to be productive and found their place in the managerial practices. While the practice of strategic management in the major foreign countries was successfully using the Soviet Union's strategic practices of the national economy development, in Russia, starting from the late 1980s, the using of the Western recipes of the administration of state and its regions did not bring any positive results.

The epochal crisis, in which Russia found itself in the late 20th century, and huge difficulties in the administration of the state and its regions, that occurred back then and still remain unsolved, prove the inadequacy of the adopted variant of economic reforms with regard to the demands of the time and the conditions within the country. A fundamentally different concept of reforms was probably needed, which would be oriented not towards sweeping destruction of the existing economic structure of the Soviet Union, but towards the country's gradual entering the market through, first and 
foremost, small businesses, as well as towards the well-thought-out and step-by-step implementation of the market mechanisms at big and medium industrial enterprises and in other sectors of economy [23].

In the major Western countries, which widely declare their liberaland-market approaches to the social and economic development, the real goals and tasks of strategic management and the practices of fulfilling them have always been guided not by these ideas, but by something else entirely - achieving the political priorities given to these countries, and the economic advantages reached by transnational corporations in severe competition at the world markets. In Russia the exaggeration of the importance of the ideas of liberal-and-market economy and reasonability of using those for development of the national economy in our country did nothing at all for strengthening of its potential. Even after the market reforms of the 1990s the Russian economy found itself among the developing and far from the leading economies of the world. And despite the fact that, starting from the 2000s, we have managed to somewhat improve our ranking, the Russian Federation and its regions, nevertheless, are currently still in need of a new relevant strategy of social and economic development.

We should be realistic about the fact that today our results, which are not that outstanding at all, and our various miscounts in strategic state, regional and corporate management are mostly based on disregarding the traditions of Russian entrepreneurship of the times before the Revolution and our own practices of highly efficient development of the national economy of the times of the Soviet period of the 1930-1960s, on the non-willingness or inability to draw a lesson from the badly thought-out and organized reforms of the late 1980-1990s, and also on exaggerating the significance of the foreign practices for the evolving of market relationships in modern Russia.

The structure of the Russian economics, which has formed, implies that the gross domestic product dynamics in the nearest future will be mostly determined by the dynamics of industrial production, and the government must do everything it can to strengthen and develop the enterprises in all the sectors of Russian industry [20].

There is also another important aspect. In the context of the eliminated subsidies for the housing and utilities sector, the expenses of the population on the housing and utilities services will increase; and if the government does not compensate for this increase, this may become a serious hindrance for the country's development. 
Among the peculiarities of the formed production and economy complex in modern Russia, we should name the following: territorial disunity of the production and economy entities; imbalance in the development of industrial sectors, which has become even more obvious over the years of reforms; declarative and non-specific character of many tasks on managing the country and its regions; and vague responsibilities at many levels in the structure of the state regional administration.

The changes in the political regime and shifting of the economics towards the market relationships still did not allow Russia to make the desiredby-the-government step towards the core upgrade of the socialist economy, which had deteriorated over the years of stagnation, and of its "heart" - the industrial complex, which until today has mostly preserved the approaches, methods and technologies of the industry and economics management that had evolved back in the era of the command-and-control system.

Ensuring the high rate of the economic growth in Russia and its regions is a crucial task of strategic importance. The future of our country directly depends on how well we will be able to raise the level of our key industrial productions to the level of those in the economically highly developed nations. It is absolutely necessary for Russia to achieve economic indicators and results higher than those in the Western countries. Unfortunately, there is an obvious imbalance in the Russian economics and industry in favor of the development of the mining and metallurgy low-added value productions. In this context, at their current dynamics, the rates of upgrading the mechanical engineering complex and crucial high-technology productions will not allow Russia to occupy any significant place in the world's ranking of the industrially developed countries, neither in the nearest, nor in the distant future. Due to the practically insurmountable difficulties on the way towards the competition in super-technologies between the world's superpowers, today Russia is considering totally different concepts for its technological breakthrough, which are based on the idea of outperforming the Western competitors without the need to catch up with them, i.e. by means of creating breakthroughs in those fields of innovative-production activity where the technologically most developed foreign superpowers have not yet managed to achieve outstanding scientific-and-engineering results, or have never ventured into these fields of innovative development.

Speaking of these innovative fields of development of Russia, one should not think that it would be that easy to compensate for such a big gap 
in the field of critically important technologies. This is a colossal scientificand-engineering problem, and its solving might require huge and mutually coordinated efforts by big groups of scientists from various fields, as well as significant financial expenses [60].

The problem of Russia's technologically lagging behind the world's leading superpowers is also aggravated by the fact that, over the years of reforms, our country has not managed to create an efficient managerial paradigm, which would have not only ensured the solving of the pressing issues of state and regional administration, but also facilitated the forming and fulfillment of the strategic goals and tasks of the social and economic development. We also did not manage to create any methodologies, models, instruments or mechanisms (adequate to the declared goals in the market economy) of managing the development of various sectors of the national economy; or the relevant methods, technologies and systems of analytical and information preparation to making managerial decisions. The majority of the scientific developments in the field of state administration in the Russian Federation entities do not aim at the complex solving of the most pressing issues in the regions' social and economic development. As a result, the government authorities' regulatory actions with regard to the production processes are mostly related to prohibitive, fiscal measures; and the state regional administration itself is situation-centered and does not allow to plan and fulfill the solving of significant strategic tasks, even short-term.

Today, in order to improve the efficiency of regional management, a well-thought-out modern and integral system is needed for managing the social and economic development of territories, the tasks of which will include not simply monitoring the activities of industrial enterprises and other economic entities, but rather ensuring the increase in the rates of growth of the industrial production and of other indicators of the territorial-production dynamics. It would be impossible to achieve this goal without an all-round scientific substantiation of the concept and technology of creating such a system.

Forming of modern strategy of a region's social and economic development should be fulfilled as follows.

1. The strategy of the region's social and economic development should be considered as an integral structure of subsystems taking into account the whole range of its natural, economic and social components, which constitute a unified territorial complex with multiple intricate internal and external relations [22]. However, it is extremely difficult to ensure a 
well-balanced development of such a complex in practice, due to a huge number of the mentioned components, the factors affecting them, as well as the criteria and limitations for such a task. Besides, the forecast and planned indictors of economic regulation, which characterize the social and economic situation within a Russian Federation entity, often look not like a scientifically substantiated complex of interconnected parameters, but rather like some sort of a conglomeration of data on good intentions of regional authorities. That is why, the region's strategy of social and economic development should be elaborated in a consistent manner and supported by serious scientific and technical-and-economic substantiation [60].

The state authorities in the Russian Federation entities can and must influence the economic growth by means of regulating the tax burden, spending of the public finances, granting, if reasonable, of budget subsidies to inefficient enterprises and of administrative protection for local enterprises against foreign competitors, etc. The effects from this impact should be calculated, and not just by means of several elementary economic computations, but by creating variance models using modern information and analytical systems and decision-making technologies [21].

2. The first step in the process of creating the region's development strategy should comprise:

- analyzing the formed paradigm of state administration in the region's industry and economics, including the methods and technologies of analyzing the dynamics of development of the industry, the existing system and structure of managing the social and economic development, the concepts and programs of the industrial and social policy [20];

- substantiating and elaborating the theoretical provisions, methods and mechanisms of the system integration of the processes of regulating the region's social and economic development, as well as of the complex reorganization of the structural schemes of managing the industry and economics, which have formed in the practices of the executive authorities in the Russian Federation entity [22];

- determining the most significant principles, requirements, means and instruments of the regional policy, on which it would be reasonable to base the elaboration of the concepts and programs of supporting the industry and other spheres of management in the region [21].

It is necessary to analyze the social and economic status of the region in the totality of the fields of its production-and-economic activities; and 
compare the relevant set of indicators, provided by the state and regional statistics, to the available data obtained as a result of monitoring the functioning of the industrial enterprises. Based on the results of such work, it becomes possible to determine the trends in the activities of the region's industrial enterprises, which would allow to make forecasts for the given dynamics for different forecast periods (short-, medium-, and long-term).

To assess the technological development of the region's industrial enterprises in certain sectors, it is possible to use a model given, for instance, in work [59].

3. To solve the tasks indicated in para. 2 , it is required to:

- develop and obtain approval for the method of efficient interaction between the state authorities and industrial enterprises on the territory of the Russian Federation entity;

- create a complex of modern models of managing the development of regional industry and other fields of national economy, based on mathematical methods of multicriteria optimization, etc.;

- implement a modern information-and-analytical system for managing the region's industry and economics into the practices of the state authorities of the Russian Federation entities [60].

The strategic priorities in the social and economic development of industrial enterprises in the Russian Federation entity should be formed through a system of supporting the making of managerial decisions on the region's development, which would include the earlier mentioned methods, models and program complexes of the information-and-analytical system.

4. Russian Federation entities should elaborate the strategies of their social and economic development in compliance with the Forecast of the Science and Technology Development in the Russian Federation for the Period till 2030 [61], and be guided by a list of regulatory documents [62-65 et al.].

5. Since Russian Federation entities, in their essence, are integral formations with a unified wide range of natural, economic and social components, and are interested in proportionate and well-balanced development of those, it means that in order to ensure the strategic industrial and economic priorities of these regions, it is necessary to perform a complex analysis of the supporting infrastructure subsystems (engineering and technical facilities and communications, resources of all kinds, etc.) for the industrial enterprises being developed. Various program complexes solving these tasks should be productively used as part of the information-and-analytical system 
of regional management [60]. Such system may be based on geoanalytical portals, which allow to analyze different layers of the region's territories; on expert systems; on systems supporting making decisions on forming the strategies of social and economic development of the Russian Federation entity, as well as agglomerations, cities and administrative districts being part of it. The information-and-analytical system of regional management should "be able" to successfully interact with relevant information systems of the federal center and provide for the correspondence of the indicators of the social and economic development within digital economy [23].

The administration of Russian Federation entities should organize support for national IT leaders in regions, as well as achieve the inflow of IT specialists to all the spheres of the national economy. Starting from the 2010s, this process has already been successfully developing, and the task, that the country entities' state authorities set before themselves, comprises the intensification of this process's dynamins based on Internet technologies, including the development of "online economics", "new economics", "smart economics", and "Runet economics" ("Russian Internet economics"). This fully facilitates the creation of efficient managerial models, including "smart house", "smart city", and "smart region".

6 . The concepts and programs of the social and economic development of regions should not only be properly elaborated and informationally tied to relevant federal programs. The viability and efficiency of those cannot be ensured without the big industrial enterprises' participating in their fulfillment based on public-private partnership [46, 47, 57]. In particular, this is the essence of the social responsibility of businesses, which should be actively participating in the region's development and not distancing themselves from solving crucial social and economic tasks related to its development.

We should note that the businesses' social responsibility abroad, and lately in Russia as well, has become an important component in improving the efficiency of regional management [49]. According to the world practices, the index of a company's sustainable development is calculated taking into account three key indicators: economics, ecology and social policy. Namely these are considered to be the main fields of activity of enterprises and organizations within the frameworks of support to the system of regional development on behalf of businesses.

7. No matter the scale of the regional development plans and the ambitions within those, as formed by the regional departments of state authorities, 
all of that can only be fulfilled by the population of those entities. In this context, the leadership of Russian Federation entities should have a clear understanding of the current demographic situation in those entities and of the objectively substantiated trends of changing it. In the cases when new big industrial enterprises and other facilities are planned to be built on the territories of those entities, the regional authorities shall think through which groups of population (as well as of migrants) should be involved for these purposes. Meanwhile, the provisions and indicators of the demographic policy of the Russian Federation entities should be interconnected with their federal analogues [23].

8. The strategy of social and economic development of any region, as a rule, comprises the programs for development of the secondary and higher professional education, the forming of which should be based on the forecasts of the demographic increase of population, development of industrial enterprises and organizations located on the region's territories, etc. It is reasonable to elaborate these programs with consideration to the industrial enterprises' and organizations' needs for labor resources, including highly qualified specialists in relevant engineering fields, as well as in management, i.e. for highly professional top managers $[24,46]$.

9. It is impossible to fulfill the strategies of the development of Russian Federation entities without such an important component as public healthcare. The regions of our country not always pay due attention to this component. What we mean is that public healthcare and medical institutions shall support the processes of development of the region's industrial enterprises, various infrastructure projects, agricultural production, etc. Special attention, when forming such a strategy, should be paid to prevention of different diseases, to epidemiological measures, and co on. For industrially developed regions, one of the key tasks is to ensure ecological protection for the nature and residents of the relevant settlements. The region's public healthcare financing should not be an exclusive burden of the state authorities. It is absolutely necessary that private businesses and different commercial entities also take part in this process. It is important to see the totality of certain steps and other measures in this field already at the stage of elaborating the region's development strategy.

We should not that the social and ecological responsibility of businesses is part of the ethical norms, alongside the system of norms and requirements related to the environment protection laws [49].

The social and ecological responsibility of businesses should take the form of their voluntary and motivated participation in various events aiming 
at the minimization of negative effects of industry on the ecological situation in the region, its cities and settlements, and namely - at reducing the environment pollutions. This process should also facilitate the rational use of natural resources, saving the raw materials and energy reserves in the economic activities, recycling of waste in production cycles, preventing accidents and emergency situations, preserving of the natural territories of preferential protection, protecting the endangered species, and so on.

10. Various social programs and social protection of the population in general should be one of the crucial aspects when forming the strategies of development of Russian Federation entities. It is extremely important both for building of trust to state authorities on behalf of the population, and for industrial enterprises of the region. Increasing the social responsibility of businesses, their participation in big social projects and programs of targeted support of the population, pre-condition and actually facilitate the strengthening of national unity, and forming of a positive image of the authorities in the region [22].

\section{Conclusion}

The research studies of the conceptual foundations of the approaches to and methods of strategic management, carried out in Russia and abroad, as well as the results of practical implementation of those, allow to state that the process of managing the social and economic development of regions, like years before, are far from being perfect. This concerns both major Western superpowers and Russia in particular. In modern conditions of the regional activity, which are characterized with political, economic and social instability, as well as with increasing difficulties in doing business due to a whole complex of various reasons (cold and hybrid wars, sanctions, threats of revolutions and changes in political regimes, dismantlement of the statehood in many countries, crises with different resources, instability of international markets, etc.), the importance of strategic management of social and economic development has considerably grown. The development of states, economic districts and separate territories, performed without any planning or with bad planning, could lead to their degradation, demise or complete loss of selfsustainability. And we mean both the economic and political ones here.

Discussing the topics touched upon in this article should help representatives of the state administration of Russia and its regions comprehend, in its entirety, the current situation, the practice of elaborating the state regional strategies, as well as improve the processes of determining national 
strategic priorities and creating programs of development. The ideas and arguments on improving the efficiency of social and economic development of regions suggested in this article are intended namely for solving this crucial national-economy task.

\section{Reference}

1. Loginovskiy O.V., Maksimov A.A. Strategic management of regions: from the established approaches to taking into account the modern reality. Control sciences, 2017, no. 6, pp. 17-31.

2. Ackoff R.L. Planning the Corporate Future, Moscow, Sirin, 2002. 255 p.

3. Vasilenko I.A. State Administrative Management in Western Countries: USA, United Kingdom, France, Germany, Moscow, Logos, 2000, 200 p.

4. Veduta E.N. Strategy and Economic Policy of a State. Moscow, Academic Project, 2004. 456 p.

5. Gaidar Ye.T. Demise of an Empire. Lessons for Modern Russia. Moscow, Rossiyskaya politicheskaya entsiklopediya (Russian Political Encyclopedia), 2006. $440 \mathrm{p}$.

6. Gaidar Ye.T. Long Time. Russia in the World: Essays on Economic History. Moscow, Delo, 2005. 656 p.

7. Gaponenko A.L. Strategy of Social and Economic Development: Country, Region, City. Moscow, Omega, 2012. 327 p.

8. Golovko I.S. Complex Programs of Social and Economic Development for Municipalities:Experience, Problems, Recommendations. Novosibirsk, 2012. $544 \mathrm{p}$.

9. Goncharov P.K. Social State: Essence, World Practices, Russian Model. Socgum-Zhurnal. 2013, no. 2, pp. 18-37.

10. Glazyev S.Yu. Genocide. Moscow, TERRA, 1998. 320 p.

11. Glazyev S.Yu. Development of Russian Economics in the Context of Global Technology Shifts: Scientific Report. Moscow, NIR, 2007. 134 p.

12. Granberg A.G., Suslitsyn V.A. Introduction to System Modelling of National Economy, Novosibirsk, Nauka, 1988. 304 p.

13. Gnevko V.A. State and Municipal Management. St.-Petersburg, IUE, $2001.350 \mathrm{p}$.

14. State Administration: Basics of Theory and Organization. Ed. by V.A. Kozbanenko, S.P. Kolomiytsev, N.S. Sleptsov. Moscow, Statut, 2000. 912 p.

15. Zerkin D.P., Ignatov V.G. Basics of the Theory of State Administration. Rostov-on-Don, MarT, 2000. 448 p.

16. Zabelin P.V., Moiseeva N.K. Basics of Strategic Management. Moscow, Vysshaya Shkola, 2006. 125 p. 
17. Karaganov S.A. Strategy for Russia: Agenda for the President. Moscow, Vagrius, 2000. 352 p.

18. Kondratiev N.D., Yakovets Yu.V., Abalkin L.I. Big Cycles of Conjuncture and the Theory of Anticipation: Selected Works. Moscow, Ekonomika (Economics), 2002. $767 \mathrm{p}$.

19. Koritskiy E.B., Nintsiyeva G.V., Shetov V.Kh. Scientific Management: Russian History. St.-Petersburg, Piter, 1999. 384 p.

20. Loginovskiy O.V., Bolodurina I.P. Governmental Management of Industry in the Russian Federation Regions: Scient. Publ. Moscow, Mashinostroeniye (Mechanical Engineering), 2003. 368 p.

21. Loginovskiy O.V., Ryazanov N.M. Regional Bodies of State Authorities in Russia in the Context of Transforming the System of Administration: monography. Yekaterinburg, UrO RAN (Ural Division of Russian Academy of Sciences), 2003. 519 p.

22. Loginovskiy O.V., Ryazanov N.M. Regional Development Management: Scient. Publ. Moscow, Mashinostroeniye (Mechanical Engineering), 2006, vol. 3. $560 \mathrm{p}$.

23. Loginovskiy O.V., Yelagin V.V. Managing the Social and Economic Development of State: Scient. Publ. Moscow, Mashinostroeniye (Mechanical Engineering), 2006, vol. 4, 544 p.

24. Loginovskiy O.V., Gollay A.V., Dranco O.I., Shestakov A.L., Shinkarev A.A. Effective management of organizational and production structures: monograph. Ed. by O.V. Loginovskiy. Moscow, INFRA-M, 2020. 450 p.

25. Lvov D.S. Development of the Russian Economics and the Tasks of the Economic Science. Moscow, Ekonomika (Economics), 1999. 79 p.

26. Lvov D.S. Economics of Development. Moscow, Ekzamen, 2002. 512 p.

27. Napreenko V.G., Narinyani A.S., Smirnov E.P. Modeling of Regional Economics: New Level of Quality and Security. Finances, Economy, Security. 2005, no. 4 (9), pp. 34-38.

28. Novikov D.A. Theory of Organization Systems Management. Moscow, FIZMATLIT Publishing House, 2012. 604 p.

29. Prokhorov A.P. Russian Model of Management. Moscow, EKSMO, 2006. 384 p.

30. Path to the 21st Century: Strategic Problems and Prospects of Russian Economics. Head of a collect. of auth. D.S. Lvov. Moscow, Ekonomika (Economics), 1999. $793 \mathrm{p}$.

31. Russia and the World. New Epoch. 12 Years That Can Change Everything. Resp. edit. and head of a collect. of auth. S.A. Karaganov. Moscow, AST, Rus-Olimp, 2008. 444 p.

32. Russia 2015: Optimistic Scenario. Ed. by L.I. Abalkin. Moscow, MMVB, 1999. 416 p. 
33. Strategic Response of Russia to the Challenges of the New Century. Under gen. ed. of L.I. Abalkin. Moscow, Ekzamen, 2004. 608 p.

34. Strategy and Problems of Sustainable Development of Russia in the 21st Century. Edit. by A.G. Granberg [et al.]. Moscow, Ekonomika (Economics), 2002. 414 p.

35. Scenario and Prospects of Development of Russia. Ed. by V.A. Sadovnichy [et al.]. Moscow, Lenand, 2011. 320 p.

36. Managing the Social and Economic Development of Russia: Concepts, Goals, Mechanisms. Head of a collect. of auth. D.S. Lvov, A.G. Porshnev. Moscow, Ekonomika (Economics), 2002. 702 p.

37. State and Regional Administration. Moscow, IKF EKMOS, 2002. 320 p.

38. Fedorenko N.P. Russia: Lessons of the Past and Images of the Future. Moscow, Ekonomika (Economics), 2000. 489 p.

39. Held D., Goldblatt D., McGrew A., Perraton J. Global Transformations: Politics, Economics, and Culture: transl. from Eng. by V.V. Sapov [et al.]. Moscow, Praksis, 2004. 576 p.

40. Erhard L. Welfare for All. Moscow, Nachalo-press, 1991. 335 p.

41. Aaker D. Strategic Market Management: transl. from Eng. St-Petersburg, Piter, 2002. 544 p.

42. Ansoff I. The New Corporate Strategy. St-Petersburg, Piter Kom, 1999. $416 \mathrm{p}$.

43. Burkov V.N., Korgin N.A., Novikov D.A. Introduction into the Theory of Organization Systems Management. Ed. by D.A. Novikov. Moscow, LIBROKOM Book house, 2009. 264 p.

44. Burkov V.N., Burkova I.V., Goubko M.V. Management Mechanisms: Organization Management: Planning, Organizing, Stimulating, Controlling: Teaching Guide. Ed. by D.A. Novikov. Moscow, Lenand, 2013. 216 p.

45. Gurney B. Introduction to the Science of Management: transl. from French. Moscow, 1989. 350 p.

46. Korennaya K.A., Loginovskiy O.V., Maksimov A.A. Management at Industrial Enterprises in the Context of Global Instability: Monography. Ed. by A.L. Shestakov. Chelyabinsk, SUSU Publishing Centre (South Ural State University), 2013. $403 \mathrm{p}$.

47. Loginovskiy O.V., Maksimov A.A. Management at an Industrial Enterprise: Scient. Publ. Moscow, Mashinostroeniye (Mechanical Engineering), 2006, vol. $1.603 \mathrm{p}$.

48. Mintzberg H., Ahlstrand B., Lampel J. Strategy Safari. St-Petersburg, Piter, 2002. $336 \mathrm{p}$.

49. Pashtova L.G., Komel'kov M.V. Business Social Responsibility: World Trends and Domestic Characteristics. Financial Analytics: Science and Experience. 2017, no. 8, pp. 895-911. 
50. Thompson A.A, Strickland A.J. Strategic Management: Concepts and Cases: transl. from Eng. Moscow, Vilyams, 2007. 928 p.

51. Gelrud Ya.D., Loginovskiy O.V. Project Management: Monography. Ed. by A.L. Shestakov. Chelyabinsk, SUSU Publishing Centre (South Ural State University), 2015. $330 \mathrm{p}$.

52. Hanke J.E., Wichern D.W., Reitsch A.G. Business Forecasting: transl. from Eng. Moscow, Vilyams Publishing House, 2003. 656 p.

53. Sheldrake J. Management Theory: From Taylorism to Japanization: transl. from Eng. Ed. by. V.A. Spivak. St-Petersburg, Piter, 2001. 352 p.

54. Burkov V., Goubko M., Korgin N., Novikov D. Introduction to Theory of Control in Organizations. Boca Ra-ton. London, CRC Press, 2015. 346 p.

55. Burkov V.N., Novikov D.A., Shchepkin A.V. Control Mechanisms for Ecological-Economic Systems. Berlin, Springer, 2015. 174 p.

56. Korennaya K.A., Loginovskiy O.V., Maksimov A.A., Zimin A.V. Global Economic Instability and Management of Industrial Organisations. Ed. By A.L. Shestakov. Kostanay, KSU, 2014. 230 p.

57. Loginovskiy O.V., Maksimov A.A. Corporate Management: Scient. Publ. Moscow, Mashinostroeniye (Mechanical Engineering), 2007, vol. 2. 624 p.

58. Abalkin L.I. Economic Strategy for Russia: The Problem of Choice. Moscow, IE RAN (Institute of Economics of Russian Academy of Sciences), 1997.

59. Gollay A.V., Loginovskiy O.V. Managerial Decision-making Model Taking into Account Technological Development of the Enterprise. Bulletin of SUSU. Ser.: Computer Technologies, Automatic Control \& Radioelectronics. 2017, no. 4 , pp. $142-145$.

60. Loginovskiy O.V., Kozlov A.S. Information Systems in Governmental Management: Monography. Ed. by A.L. Shestakov. Chelyabinsk, SUSU Publishing Centre (South Ural State University), 2013. 456 p.

61. Forecast of the Science and Technology Development in the Russian Federation for the Period till 2030. URL: http://static.government.ru/media/ files/41d4b737638b91da2184.pdf, available at: 11 November 2017.

62. Decree by the Russian Federation President No. 642 On the Strategy of Science and Technology Development of the Russian Federation as of 01.12.2016 URL: http://www.kremlin.ru/acts/bank/41449, available at: 11 November 2017.

63. Decree by the Russian Federation President No.203 On the Strategy of Development of the Information Society in the Russian Federation for the Period of 2017-2030 as of 09.05.2017. URL: http://kremlin.ru/acts/bank/41919, available at: 11 November 2017.

64. Resolution by the Russian Federation Government No. 2036-p On Approving the Strategy of Development of the Field of Information Technologies in the Russian Federation for the Period of 2014-2020, and Long-term till the year of 
2025 as of 01.11.2013. URL: https://rg.ru/2013/11/08/texnologii-site-dok.html, available at: 11 November 2017.

65. Resolution by the Russian Federation Government No. 1632-p On Approving the Program on Digital Economy of the Russian Federation as of 28.07.2017. URL: http://government.ru/docs/28653/, available at: 11 November 2017.

Статья получена: 13.07 .2020

Статья принята: 27.08.2020

\section{About the authors}

Oleg V. Loginovskiy (Chelyabinsk, Russian Federation) - Dr. Habil in Engineering, Professor, Honored Scientist of the Russian Federation, Head of the Department of Information and Analytical Support for Management in Social and Economic Systems, South Ural State University (454080, Chelyabinsk, Lenin av., 76, e-mail: loginovskiiov@susu.ru).

Aleksandr A. Maksimov (Moscow, Russian Federation) - Dr. Habil in Engineering, Member of the State Duma, the Federal Assembly of the Russian Federation (103265, Moscow, Okhotny Ryad st, 1).

Aleksandr L. Shestakov (Chelyabinsk, Russian Federation) - Dr. Habil in Engineering, Professor, South Ural State University (454080, Chelyabinsk, Lenin av., 76, e-mail: admin@susu.ru).

\section{Библиографическое описание статьи согласно ГОСТ Р 7.0.100-2018:}

Loginovskiy, O.V. Strategic management of the regions in the context of domestic and foreign experience $=$ Стратегическое управление регионами с учетом отечественного и зарубежного опыта / O. V. Loginovskiy, A. A. Maksimov, A. L. Shestakov. DOI 10.15593/2499-9873/2020.3.07. - Текст : непосредственный // Прикладная математика и вопросы управления = Applied Mathematics and Control Sciences. $-2020 .-$ № 3. - С. 123-149. - Ст. на англ. языке.

\section{Цитирование статьи в изданиях РИНЦ:}

Loginovskiy O.V., Maksimov A.A., Shestakov A.L. Strategic management of the regions in the context of domestic and foreign experience. // Прикладная математика и вопросы управления. - 2020. - № 3. - С. 123-149. DOI: 10.15593/2499-9873/2020.3.07

\section{Цитирование статьи в references и международных изданиях:}

\section{Cite this article as:}

Loginovskiy O.V., Maksimov A.A. Shestakov A.L. Strategic management of the regions in the context of domestic and foreign experience. Applied Mathematics and Control Sciences, 2020, no. 3, pp. 123-149. DOI: 10.15593/2499-9873/2020.3.07 